\title{
Changes in the Amount of Myelocyes in the Thymus During its Accidental Involution in Young Rabbits
}

\author{
By \\ Korenobu Karasawa \\ Department of Anatomy, Yamaguchi Medical School, Ube \\ (Director: Prof. Dr. B. Osogoe)
}

The presence of myelocytes in relative large numbers in the thymus of some mammals (mouse, rat, guinea-pig, rabbit and man) has been described many times (Maximow, 1909; Weidenreich, 1912; Weill, 1913; Shiraki, 1934; Downey, 1948; and others), but there is no agreement on the orgin and significance of these cells. Maximow, Weiden reich and Downey claim that the myelocytes are derived from the thymic lymphocytes, whereas Hart (1912) and Fulci (1913) believe the blood or connective tissue to be the most likely source.

Recently Ōmura and Yamasowa (1952) in this laboratory made a quantitative study on the age variations in the amount of thymic myelocytes in normal rabbits and guinea-pigs from birth up to old age. They have demonstrated that the myelocytes in the thymus occur as a remnant of embryonal hematopoiesis and participate in granulocytopoiesis in postnatal life, and that their number per unit area of the parenchyma in sections increases with thymic growth, parallel to the rise of the hemotopoietic activities of the bone marrow. On the basis of these findings, it is concluded that the granulocytopoiesis of the thymus is a phenomenon clearly distinguishable from the so-called extramedullary hematopoiesis which represents a compensatory mechanism for insufficient marrow functions.

Further studies by these investigators revealed that in the rabbit thymus the number of myelocytes was much increased during the early period of age involution. A similar increase in the number of myelocytes during pathologic involution of the human thymus has been reported by Ssyssojew (1923). However, no quantitative date on the changes in the amount of myelocytes during the process of involution 
are available. Therefore, the author made a quantitative study to be described below.

\section{Material and Method}

Young healthy rabbits weighing 1.0 to $1.8 \mathrm{~kg}$, whose thymus is well developed without showing any indication of involution, were used. In order to induce a rapid involution of the thymus, an alarming dose of formalin was injected according to the method of Selye (1938). Namely, 0.8 to $1.1 \mathrm{ml}$ of $35 \%$ formaldehyde per kilogramme body weight was injected subcutaneously into the back of each animal 4 times at intervals of 12 hours. From 6 hours to 28 days after the last injection of formalin, the animals were killed serially, and the thymus, mesenteric and popliteal lymph nodes, Peyer's patches of small intestine, bone marrow, spleen and liver were fixed in Zenker-formol, embedded in paraffin and sectioned at $6 \mu$. The sections were stained routinely with hematoxylin and eosin or eosin-azur II.

Differential counts of the thymic myelocytes were made in sections from different parts of the thymus. Since the myelocytes appeared almost exclusively in the parenchyma, the counts were confined to the parenchyma. Accordingly, the numbers of myelocytes listed in Tables 1 and 2 represent the values for $1 \mathrm{~cm}^{2}$ of parenchyma in thymic sections, the septal and fat tissues being excluded.

\section{Observations and Discussion}

As seen in Table 1, the thymus underwent a marked involution within 72 hours after the last injection of formalin, both its weight and relative area of the parenchyma in sections being reduced to a large extent. The most advanced stage of involution was reached on the 5th to 10th day after the last injection. With the progress of involution, the cellularity of lymphocytes in the parenchyma became scanty through degeneration of these cells, whereas the number of myelocytes per unit area of parenchyma in sections (here termed the concentration of myelocytes*) was considerably increased. During the course of the first 7 to 10 days, there seemed to be a parallelism between the progress of involution and the concentration of myelocytes - the more pronounced the thymic involution, the greater was the

* The number of myelocytes per unit area of parenchyma in sections will be expressed in brief as "the concentrarion of myelocytes" in the following. 
concentration of these cells. It should be noticed here that in advanced stages of accidental involution the concentrations of myelocytes were much higher than those observed during age involution.

Regeneration of the thymic parenchyma began to occur on the 7th to 10th day, but it proceeded very slowly so that the thymus was still in an advanced stage of involution up to the 28th day. Coincident with the commencement of regeneration of the thymic parenchyma, the

Table. 1. Changes in the total number of the thymic myelocytes constained in $1 \mathrm{~cm}^{2}$ of parenchyma in sections $(6 \mu)$, in relation to the weight of thymus and the degree of its involution as well as to the degree of hyperplasia of the bone marrow myelocytes, after 4 injections of 0.8 to $1.1 \mathrm{ml}$ of $35 \%$ formaldehyde per kilogramme body weight.

\begin{tabular}{|c|c|c|c|c|c|c|}
\hline $\begin{array}{l}\text { Time after the } \\
\text { last injection }\end{array}$ & $\begin{array}{c}\text { Rabbit } \\
\text { No. }\end{array}$ & $\begin{array}{c}\text { Body } \\
\text { weight } \\
(\mathrm{kg})\end{array}$ & $\begin{array}{l}\text { Weight } \\
\text { of } \\
\text { thymus } \\
(\mathrm{g})\end{array}$ & $\begin{array}{c}\text { Relative } \\
\text { area of } \\
\text { parenchyma } \\
\text { in sections* } \\
(\%)\end{array}$ & $\begin{array}{l}\text { Total number of } \\
\text { myelocyte per } \\
1 \mathrm{~cm}^{2} \text { of paren- } \\
\text { chyma in sec- } \\
\text { tions }(6 \mu .)\end{array}$ & $\begin{array}{l}\text { Hyperplasia } \\
\text { of marrow } \\
\text { myelocytes }\end{array}$ \\
\hline $\begin{array}{l}\text { Control } 1 \\
(60 \text { days of age })\end{array}$ & $\begin{array}{l}\text { Average } \\
3 \text { rabbits }\end{array}$ & 0.83 & 1.50 & $\begin{array}{c}\text { no involution } \\
(100 \%)\end{array}$ & 2,440 & 一 \\
\hline $\begin{array}{c}\text { Control } 2 \\
\text { (90 days of age) }\end{array}$ & $\begin{array}{l}\text { Average } \\
2 \text { rabbits }\end{array}$ & 1.4 & 2.50 & $\prime \prime$ & 1,440 & 一 \\
\hline $\begin{array}{c}\text { Control } 3 \\
\text { (120 days of age) }\end{array}$ & $\begin{array}{l}\text { Average } \\
2 \text { rabbits }\end{array}$ & 1.7 & 2.45 & $"$ & 1,770 & - \\
\hline$\left(\begin{array}{c}\text { Control } 4 \\
(150 \text { days of age })\end{array}\right.$ & $\begin{array}{l}\text { Average } \\
2 \text { rabbits }\end{array}$ & 1.9 & 3.18 & $"$ & 1,710 & - \\
\hline 6 hours & No. 18 & 1.2 & 1.62 & $60 \%$ & 2,940 & - \\
\hline 12 hours & No. 4 & 1.3 & 3.07 & 73 & 3,220 & - \\
\hline 12 hours & No. 1 & 1.0 & 0.64 & 69 & 4,260 & - \\
\hline 24 hours & No. 21 & 1.2 & 3.20 & 66 & 5,570 & - \\
\hline 48 hours & No. 19 & 1.4 & 0.65 & 59 & 6,180 & - \\
\hline 48 hours & No. 12 & 1.7 & 1.18 & 57 & 8,510 & - \\
\hline 72 hours & No. 22 & 1.0 & 0.12 & 17 & 5,400 & - \\
\hline 5 days & No. 20 & 1.1 & 0.30 & 50 & 2,440 & 一 \\
\hline 7 days & No. 15 & 1.1 & 0.30 & 34 & 9,160 & H \\
\hline 7 days & No. 5 & 1.6 & 0.30 & 42 & 24,130 & 册 ** \\
\hline 10 days & No. 16 & 1.1 & 0.20 & 18 & 9,660 & \# \\
\hline 10 days & No. 9 & 1.8 & 0.50 & 25 & 1,760 & \# \\
\hline 14 days & No. 17 & 1.2 & 0.14 & 22 & 1,800 & - \\
\hline 21 days & No. 13 & 1.7 & 0.40 & 49 & 1,300 & - \\
\hline 28 days & No. 14 & 1.8 & 0.35 & 31 & 9.200 & - \\
\hline
\end{tabular}

* Percentage of the parenchymal area to the total area of a thymic section. The lower this value, the more pronounced is the thymic involution.

** Designation $\mathrm{ll}$ means a very marked hyperplasia of marrow myelocytes; \# a somewhat lesser degree. 
concentration of myelocytes was reduced to the control level.

In the thymus of normal rabbits, as described in the previous paper by $\bar{O}$ mura and Yamasowa (1952), the myelocytes occur almost exclusively in the parenchyma, being either scattered or in small clusters and often in mitosis. They are most numerous in the outer portion of the cortex (Fig. 1). With the advance of involution, they became more closely aggregated in the reduced parenchyma, which is composed of loosely packed lymphocytes among meshes of reticular stroma without distinction of cortex and medulla. In the most advanced stages of involution, the myelocytes often occurred in large clusters intermingled with lymphocytes, so that the picture at these sites was reminiscent of hypoplastic bone marrow (Figs. 2-3).

Table 2. Differential counts of the thymic myelocytes contained in $1 \mathrm{~cm}^{2}$ of parenchyma in sections $(6 \mu)$, after 4 injections of 0.8 to $1.1 \mathrm{ml}$ of $35 \%$ formaldehyde per kilogramme body weight.

\begin{tabular}{|c|c|c|c|c|c|c|}
\hline \multirow{2}{*}{$\begin{array}{l}\text { Time after the } \\
\text { last injection }\end{array}$} & \multirow{2}{*}{$\begin{array}{c}\text { Rabbit } \\
\text { No. }\end{array}$} & \multirow{2}{*}{$\begin{array}{l}\text { Total num- } \\
\text { ber of } \\
\text { myelocytes }\end{array}$} & \multicolumn{4}{|c|}{ Differential counts of myelocytes } \\
\hline & & & $\begin{array}{l}\text { Promy } \\
\text { elocyte }\end{array}$ & $\begin{array}{l}\text { Eosinophil } \\
\text { smyelocytes }\end{array}$ & $\begin{array}{c}\text { Pseudoeosinophil } \\
\text { myelocytes }\end{array}$ & $\begin{array}{l}\text { Metamy- } \\
\text { elocytes }\end{array}$ \\
\hline 6 hours & No. 18 & 2,940 & 290 & 240 & 1,040 & 1,370 \\
\hline 12 hours & No. 4 & 3,220 & 10 & 210 & 1,000 & 1,970 \\
\hline 12 hours & No. 1 & 4,260 & 260 & 320 & 1,220 & 2,460 \\
\hline 24 hours & No. 21 & 5,570 & 260 & 250 & 1,830 & 3,230 \\
\hline 48 hours & No. 19 & 6,180 & 130 & 310 & 2,430 & 3,310 \\
\hline 48 hours & No. 12 & 8,510 & $8 \varepsilon 0$ & 470 & 4,530 & 2,680 \\
\hline 72 hours & No. 22 & 5,400 & 330 & 260 & 1,790 & 3,020 \\
\hline 5 days & No. 20 & 2,440 & 210 & 240 & 680 & 1,310 \\
\hline 7 days & No. 15 & 9,160 & 290 & 280 & 2,730 & 5,860 \\
\hline 7 days & No. 5 & 24,130 & 880 & 690 & 10,380 & 12,180 \\
\hline 10 days & No. 16 & 9,660 & 280 & 270 & 3,640 & 5,470 \\
\hline 10 days & No. 9 & 1,760 & 20 & 170 & 850 & 720 \\
\hline 14 days & No. 17 & 1,800 & 30 & 190 & 320 & 1,260 \\
\hline 21 days & No. 13 & 1,300 & 20 & 130 & 510 & 640 \\
\hline 28 days & No. 14 & 9,200 & 210 & 270 & 4,530 & 4,190 \\
\hline
\end{tabular}

The myelocytes of the thymus in an advanced stages of involution were of the same character as those of the normal thymus, and the large majority of them were of the type similar to those of the bone marrow. They were often in mitosis, and all stages of the maturation process from the promyelocytes to the metamyelocytes and eventually into the polymorphonuclears could be followed (see Table 2). There- 
fore there is no doubt that the thymus in an advanced stage of involution also participates in granulocytopoiesis.

From these findings it is conceivable that with the progress of involution the granulocytopoietic activity of the thymus is raised to a considerable extent. However, a high concentration of thymic myelo. cytes does not necessarily imply an increase in the total amount of these cells per thymus, because in such instance the reduction in the mass of thymic parenchyma takes place to a greater extent. Calculations from the data presented in Table 1 revealed no increase in the total number of myelocytes per thymus in any instances. This implies that a high concentration of myelocytes of the thymus in an advanced stage of involution is a result of condensation of these cell in the reduced parenchyma. It may be concluded, therefore, that the granulocytopoietic activity of the thymus as a whole does not increase during its accidental involution.

Nevertheless, it is certain that so far as local granulocytopoiesis in the thymic parenchyma is concerned, its activity is increased during the process of accidental involution. Here, it is to be noticed that a close relationship is to be seen between the degenerative and regenerative processes of the thymic lymphocytes on the one hand and the activity of local granulocytopoiesis in the thymus on the other. As already stated, degeneration of the thymic lymphocytes occurred up to the 7th day, but thereafter it subsided. Simultaneously, regeneration of these cells began to occur and proceeded very slowly. The concentration of myelocytes in the parenchyma, on the other hand, was considerably increased during the first 7 to 10 days, but later it was reduced to the control level coincident with the commencement of regeneration of the thymic lymphocytes. The activity of local granulocytopoiesis in the thymus, therefore, seems to be raised by the factors which produce dissolution of the thymic lymphocytes.

In connection with this, it is of interest to note that the rise in granulocytopoietic activity of the thymus during its accidental involution was accompanied by a marked hyperplasia of the myelocytes of bone marrow (see Table 1). This suggests that an alarming does of formalin may enhance granulocytopoiesis not only in the thymus but also in the bone marrow.

Dissolution of the lymphocytes of the mesenteric and popliteal lymph nodes and Peyer's patches of small intestine was also produced, though to a lesser extent, by the injections of formalin. However, either in these nodes and Peyer's patches or in the spleen and liver, 
no foci of myelocytes occurred throughout the experimental period. Likewise, there was no indication of extramedullary erythropoiesis either in the thymus or in any other organs.

Lastly, the writer wishes to described briefly an interesting finding that in Rabbit No. 5 killed 7 day after the last injection of formalin, a small lymph node incorporated with the thymus was met with. Close examination, however, revealed a thin layer of connective tissue between the two. In this respect this lymph node differs from a similar one which was reported by Togari and Tanabashi (1949) to be completely fused with the thymus without interposing connective tissue. The lymph node observed here was in an advanced stage of involution as was the thymus, but still retained features characteristic of lymph node, having a secondary nodule with a germinal center as well as cortical and medullary sinuses (see Fig. 4). In addition, post-capillary veins with characteristic endothelial cells were found in the outer portion corresponding to the cortex. It is worthy of notice that in this node there were no myelocytes anywhere; instead, many macrophages containing erythrocytes and hemosiderin granules were seen in the portions corresponding to the medullary cords.

\section{Summary}

In young rabbits, a quantitative study was made of the changes in the amount of myelocytes in the thymus during its accidental involution. As an agent to induce accidental involution of the thymus an alarming dose of formalin was used.

It was observed that with the progress of thymic involution, the cellularity of lymphocytes in the parenchyma became scanty, whereas the number of myelocytes per unit area of parenchyma in sections (here termed the concentration of myelocytes) was considerably increased, so that not infrequently the histological picture of the thymic parenchyma was reminiscent of hypoplastic bone marrow. Even in such instances, however, the total amount of myelocytes per thymus did not increase, because the reduction in the mass of thymic parenchyma took place to a greater extent. This implies that a high concentration of myelocytes of the thymus in an advanced stage of involution is a result of condensation of these cells in the reduced parenchyma.

The concentration of myelocytes in the parenchyma was reduced to the normal level coincident with the commencement of regeneration 
of the thymic lymphocytes.

Either in other lymphoid organs or in the liver and spleen, there appeared no foci of myelocytes throughout the experimental period.

This research was conducted under the direction of Professor Bunsuke Osogoe. I wish to express my thanks to him for constant guidance in the course of the work.

\section{Literature Cited}

Downey, H. 1948. Cytology of rabbit thymus and regeneration of its thymocytes after irradiation; with some notes on the human thymus. Blood, $3: 1315-1341$.

Fulci, F. 1913. Die Natur der Thymusdrüse nach Untersuchungen über ihre Regenerationsfähigkeit bei den Säugetieren. Deutsch. med. Wochenschr., 39: 1776-1780'

Hart, C. 1912. Thymusstudien. II. Die Thymuselemente. Virchow's Arch., $210: 255-277$.

Maximow, A. 1909. Über die Histogenese der Thymus bei Säugetieren. Arch. mikr. Anat., $74: 525-621$.

Omura, K., and Y. Yamasowa. 1952. Granulocytopoiesis in the thymus of normal rabbits and guinea-pigs, with special referrence to its age variations. Acta Haemat. Jap., 15: 327-335.

Selye, H. 1930. Studies on adaptation. Endocrinology, $21: 169-188$.

Shiraki, Y. 1934. Über die hämatopoetische Funktion des Thymus der Ratte. Kaibo. Z., $7:$ 90-108.

Ssyssojew, Th. 1923. Über die Rolle der reticulären Zellen des Thymus bei seiner pathologischen Rückbildung und über die Blutbildung in ihm bei Infektionskrankheiten. Virchow's Arch., 250: 54-68.

Togari, Ch. and T. Tanabashi. 1949. On the difference between the thymocyte and the lymphocyte. Nagoya Igaku Zasshi, 63 : 124-125. (Japanese.)

Weidenreich, F. 1912. Die Thymus des erwachsenen Menschen als Bildungsstätte ungranulierter und granulierter Leukocyten. Münch. med. Wochenschr., 59 : 26012605.

W eill, P. 1913. Über die Bildung von Leukocyten in der menschlichen und tierischen Thymus des erwachsenen Organismus. Arch, mikr. Anat., 83: 305-360.

\section{Explanation of Plate}

All of the microphotographs were taken from preparations, fixed in Zenker formol and stained with hematoxylin and eosin.

1. Section through the thymus from Rabbit No. 2, illustrating a number of myelocytes in the outer portion of the cortex. Six hours after the last injection of formalin. This thymus showed an almost normal picture with a slight degree of involution. $\times 900$.

2. Section through the thymus from Rabbit No. 5. This thymus was in the most advanced stage of involution and the myelocytes were most numerous (see Table 1). Seven days after the last injection of formalin. Many large round cells represent myelocytes. $\times 360$.

3. Higher magnification of a fleld from the same section shown in figure 2. Large round cells containing granules represent myelocytes. $\times 900$. 
4. Section through a small lymph node incorporated with the thymus in Rabbit No. 5, showing a secondary nodule with a germinal center. The capsular tissue of this node on the right side is continuous to the septal tissue of the thymus. $\times 80$. 
Plate I

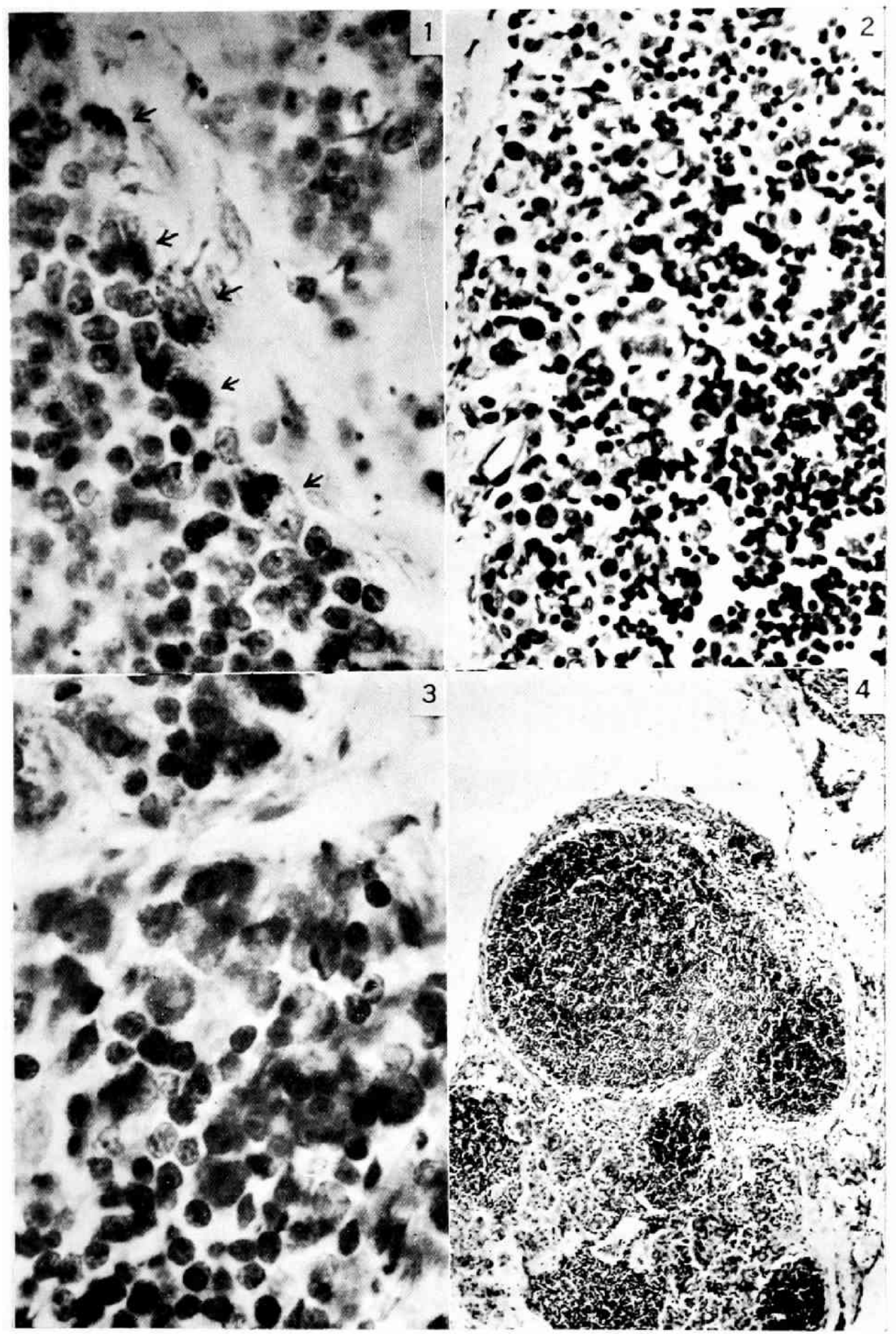

K. Karasawa 